\title{
TEMPORAL CHANGE OF RADIOCARBON RESERVOIR EFFECT IN SUGAN LAKE, NORTHWEST CHINA DURING THE LATE HOLOCENE
}

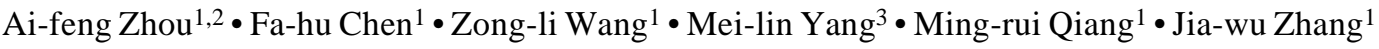

ABSTRACT. Many lacustrine chronology records suffer from radiocarbon reservoir effects. A continuous, accurate varve chronology, in conjunction with accelerator mass spectrometry (AMS) ${ }^{14} \mathrm{C}$ dating, was used to determine the age of lacustrine sediment and to quantify the past ${ }^{14} \mathrm{C}$ reservoir effect in Sugan Lake (China). Reservoir age varied from 4340 to $2590 \mathrm{yr}$ due to ${ }^{14} \mathrm{C}$-depleted water in the late Holocene. However, during the Little Ice Age (LIA), ${ }^{14} \mathrm{C}$ reservoir age was relatively stable. According to this study, ${ }^{14} \mathrm{C}$ reservoir age in the late Holocene may be driven by hydrological and climatic changes of this period. Therefore, special caution should be paid to the correction of the ${ }^{14} \mathrm{C}$ reservoir effect by a unique ${ }^{14} \mathrm{C}$ reservoir age in paleoclimatic and paleolimnological study of northwest China.

\section{INTRODUCTION}

As lake sediment records can provide potentially high-resolution, continuous terrestrial archives of environmental changes, they play an important role in the reconstruction of past climate and environment conditions. Therefore, reliable chronologies are crucial to paleoclimatic studies. Among all dating methods, radiocarbon dating is one of the most useful tools for providing a chronological framework for paleoenvironmental study of lake sediment records. The application of ${ }^{14} \mathrm{C}$ dating to lake sediments is complicated, however, by temporal and spatial variability among ${ }^{14} \mathrm{C}$ reservoir effects (Colman et al. 1996; Geyh et al. 1998; Hall and Henderson 2001). Many times, the ${ }^{14} \mathrm{C}$ reservoir effect is associated with the input of old carbon mixture by river water or groundwater subsequently absorbed by aquatic plants or authigenic carbonate, then comprising the inherited age (Hendy and Hall 2006). Similarly, the residence time effect, where water at the lake bottom is prevented from mixing with the atmosphere, produces a ${ }^{14} \mathrm{C}$ age affecting lake sediment dating (Hendy and Hall 2006). Both such effects tend to make observed ages of ${ }^{14} \mathrm{C}$ samples from aquatic material in lake sediments much older than ages of corresponding terrestrial plants.

${ }^{14} \mathrm{C}$ reservoir effects must be eliminated in order to derive robust chronologies for paleoclimatic and archaeological reconstruction. Several ways to avoid or correct the ${ }^{14} \mathrm{C}$ reservoir effect have been established. A common method is to date contemporaneous aquatic/bulk organic and terrestrial material to evaluate the reservoir effect (Chen et al. 2001; Hutchinson et al. 2004; Culleton 2006). Paired authigenic carbonate U/Th dating (Hall and Henderson 2001; Stein et al. 2004) and ${ }^{14} \mathrm{C}$ dating methods has also been used. Recently, measuring apparent ${ }^{14} \mathrm{C}$ ages with total organic carbon (TOC) or dissolved inorganic carbon (DIC) in lake water has been used by various researchers (Yu et al. 2007; Stiller et al. 2001; Moreton et al. 2004; Hendy and Hall 2006). On the other hand, paleoclimate research is used to draw a regression line between depth of the sediment and ${ }^{14} \mathrm{C}$ age to determine the ${ }^{14} \mathrm{C}$ reservoir age, then this age is subtracted directly (Shen et al. 2005) throughout the whole sediment core to get a chronological framework. However, the reservoir effect will vary temporally and spatially.

One such technique is varve counting, which can be applied in connection with the ${ }^{14} \mathrm{C}$ calibration curve. Varved sediments can give an inherent and continuous age-depth control for paleoenvironmental reconstructions and, thus, are valuable for evaluating and calibrating other sediment dating

${ }^{1}$ CAEP, Key Laboratory of West China's Environmental System (Ministry of Education), Lanzhou University, Lanzhou 730000 , China.

${ }^{2}$ Corresponding author. Email: zhouaf@lzu.edu.cn.

${ }^{3}$ Appraisal Center of Environmental Engineering of Yunnan Province, Kunming 650032, China.

(C) 2009 by the Arizona Board of Regents on behalf of the University of Arizona

Proceedings of the 5th International ${ }^{14} \mathrm{C}$ and Archaeology Symposium, edited by Irka Hajdas et al.

RADIOCARBON, Vol 51, Nr 2, 2009, p 529-535 
techniques. In many cases, varves are of poor quality or have disturbed sequences in the upper parts of the sediment record (Hajdas et al. 1995); however, they still provide a wonderful absolute dating material for constructing the chronological sequence.

A continuous, well-preserved varve sequence back to the late Holocene was discovered recently in Sugan Lake (Zhou 2007a). Although temporal changes in lake ${ }^{14} \mathrm{C}$ reservoir ages were determined in many regions, including Antarctica (Hendy and Hall 2006) and the Middle East (Stein et al. 2004; Belmaker et al. 2007), no study has yet investigated temporal changes in ${ }^{14} \mathrm{C}$ reservoir effect on lake sediment. An accurate quantification of lake reservoir age is crucial to constructing effective environmental chronologies when using material that incorporates ${ }^{14} \mathrm{C}$ from a hardwater source. The aim of the present research was to examine temporal variations in the arid lake ${ }^{14} \mathrm{C}$ reservoir effect in northwest China during the past 2730 calendar yr. Here, we assess temporal variation in reservoir values and discuss their relation to the hydrological-limnological history and climate change of the lake system.

\section{SITE AND SEDIMENTS}

Sugan Lake (38 $52^{\prime} \mathrm{N}, 93^{\circ} 53^{\prime} \mathrm{E}$; $2795 \mathrm{~m}$ asl) is located in a closed depression mosaic in the Qaidam Basin (Figure 1). The surface area amounts to $104 \mathrm{~km}^{2}$ with a mean depth of $2.8 \mathrm{~m}$ and a maximum depth of $5 \mathrm{~m}$ in the southern part of the lake. The climate of the lake region is very arid. Mean annual temperature, according to Lenghu meteorological station ( $40 \mathrm{~km}$ west of Sugan Lake), is $2.75^{\circ} \mathrm{C}$. The lake lies in the hyperarid zone of China, with an annual precipitation of $18.7 \mathrm{~mm}$ and annual potential evaporation of $2967.2 \mathrm{~mm}$ over the last $50 \mathrm{yr}$. The main sources of water for Sugan Lake are the Daharteng and Xiaoharteng rivers in the eastern part of the basin; these are fed mainly by mountain ice sheets. After reaching the Gobi zone of the piedmont plain, the river water entirely infiltrates into the subsurface layer, then part of it rises to the surface as spring water in the fine earthy plain east of the lake, and forms short, pinnate rivers to recharge the lake while part of it recharges the lake as groundwater. The lake water is highly saline $(31.83 \mathrm{~g} / \mathrm{L})$, belonging to the $\mathrm{Cl}-$ $\mathrm{SO}_{4}-\mathrm{Na}-\mathrm{Mg}$ chemical type, with a $\mathrm{pH}$ value of 8.5. The lake water has a high $\mathrm{HCO}_{3}$ content of 683.5 $\mathrm{mg} / \mathrm{L}$ and a $\mathrm{Mg}^{2+} / \mathrm{Ca}^{2+}$ ratio of 21 (Qiang et al. 2005). Measurement of temperature and conductivity in situ suggests no stratification occurred during unfrozen seasons. From mid-November to midApril, however, when the lake develops an extensive ice cover, a saline stratification occurs and the salinity of the bottom lake water rises to nearly $2 \mathrm{~g} / \mathrm{L}$ greater than the surface lake water, under the ice layer.

In January 2000, an 8.52-m-long sediment core, SG00C, was recovered on the ice cover using a piston corer from the center of Sugan Lake, with the water depth at $4.5 \mathrm{~m}$ (Qiang et al. 2005). Sediments of the core were found to be laminated through the top $5.5 \mathrm{~m}$. In January 2004, a 7.9-m-long core, SG03I, was taken at the same site. Eolian sand beneath the lacustrine sediments appeared at the bottom of the core. Sulfate crystal appeared at a depth of $574-592 \mathrm{~cm}$. The top $5.5 \mathrm{~m}$ of the core contained 4 types of fine laminated sediments that could be recognized by the naked eye. They are defined as types A, B, C, and D according to color, thickness, and structural features of the laminated couplets. Scanning electron microscope (SEM), mineral analysis, and ${ }^{210} \mathrm{~Pb}$ dating on modern lake sediments in different seasons indicate that varve structure can be formed in modern lake conditions (Zhou et al. 2007b). These 2 cores show the same characteristics in detail. Using the mark layer, the depth of core SG00C was calibrated on the same scale as core SG03I. 


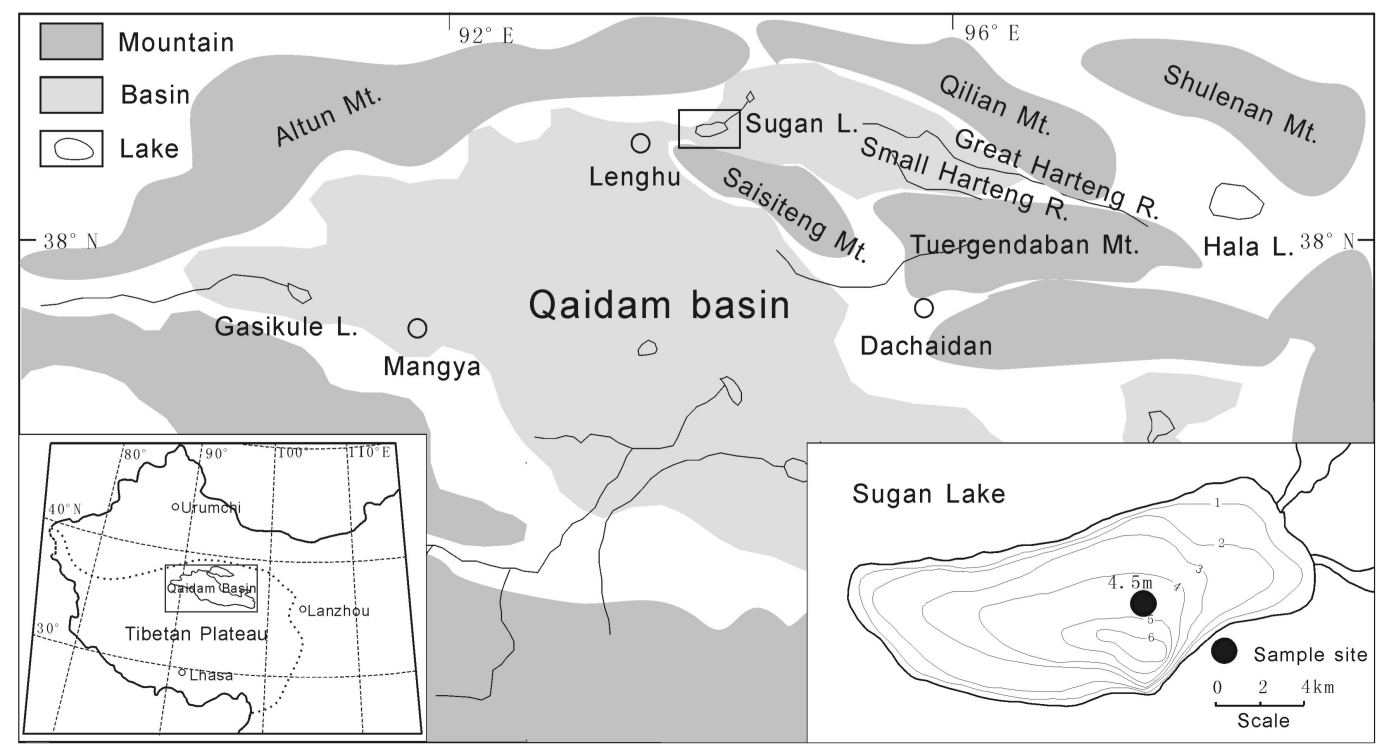

Figure 1 Map of Sugan Lake, bathymetric contour, and the core site

\section{MATERIAL AND ANALYTICAL METHODS}

Due to lack of terrestrial plant remains and charcoal in Sugan Lake sediment, ${ }^{14} \mathrm{C}$ measurements were made on 4 aquatic plant (Ruppia maritima) fossil seeds and 1 aquatic plant detritus from the long core SG00C. ${ }^{14} \mathrm{C} /{ }^{12} \mathrm{C}$ ratios were measured by an accelerator mass spectrometer at the Leibniz Laboratory, Christian-Albrechts-University of Kiel, Germany, which showed typical uncertainty around $0.5 \%$ (Grootes et al. 2004). The $\delta^{13} \mathrm{C}$ values were measured simultaneously with ${ }^{14} \mathrm{C} /{ }^{12} \mathrm{C}$ ratios. All the ${ }^{14} \mathrm{C}$ dating results of sample were corrected with the depth series as core SG03I.

Varve counting was carried out on core SG03I. Manual varve counting on the cleaned, fresh sediment surface is a quick, reliable way to establish varve chronology (Simola 1977; Renberg 1981; Goslar et al. 1989). Following the method of Renberg (1981), the frozen core was split in half lengthwise, the sediment surface was cleaned with a knife, and digital photos were taken immediately. Photoshop ${ }^{\circledR}$ software measured the thickness of individual light and dark layers. Laminations were then counted and their thickness calibrated (Ojala et al. 2005).

Calendar age and ${ }^{14} \mathrm{C}$ age are chronologies of 2 different scales: the former is a physical age, while the latter is a radiometric age. They must be calibrated into the same scale before a reservoir age can be calculated. In this paper, we set the varve age as the calendar age, and then find a relevant ${ }^{14} \mathrm{C}$ age (called the varve ${ }^{14} \mathrm{C}$ age) by using the IntCal04 calibration curve (Reimer et al. 2004).

\section{RESULTS AND DISCUSSION}

\section{Varve Chronology}

As a prerequisite, the annual nature of laminae couples have been verified by sediment-trap studies, detailed scanning electron microscope (SEM) investigations, and ${ }^{210} \mathrm{~Pb}$ dating results. Varve counting results are in agreement with ${ }^{210} \mathrm{~Pb}$ dating results. The detailed methods of the varve confirmation are described in Zhou et al. (2007b). 
The basic structure of Sugan Lake varves is simple. Most varves consist of 2 layers, a light layer chemical mineral deposit and a dark layer physical and biologic deposit. The dark and light layers of the laminae couplets, with their distinctive minerals, characterize the seasonal variations of the summer half-year and the winter half-year (Zhou et al. 2007b). Simple but careful manual documentation of varves from the cleaned, fresh sediment surface is an effective, fairly quick way of registering and counting varves (Ojala and Saarnisto 1999).

A continuous age-depth curve based on varve counting was established from core SG03I tracking back to the last $2732 \mathrm{yr}$ (Figure 2a). The mean varve thickness is about $2.1 \mathrm{~mm}$, and the cumulative uncertainty of varve chronology is less than $2 \%$. Due to the annual nature of varve, we use "varve ${ }^{14} \mathrm{C}$ age" throughout this paper. All the "varve calendar years" were converted into "varve ${ }^{14} \mathrm{C}$ ages" by IntCal04 calibration curve (Reimer et al. 2004).
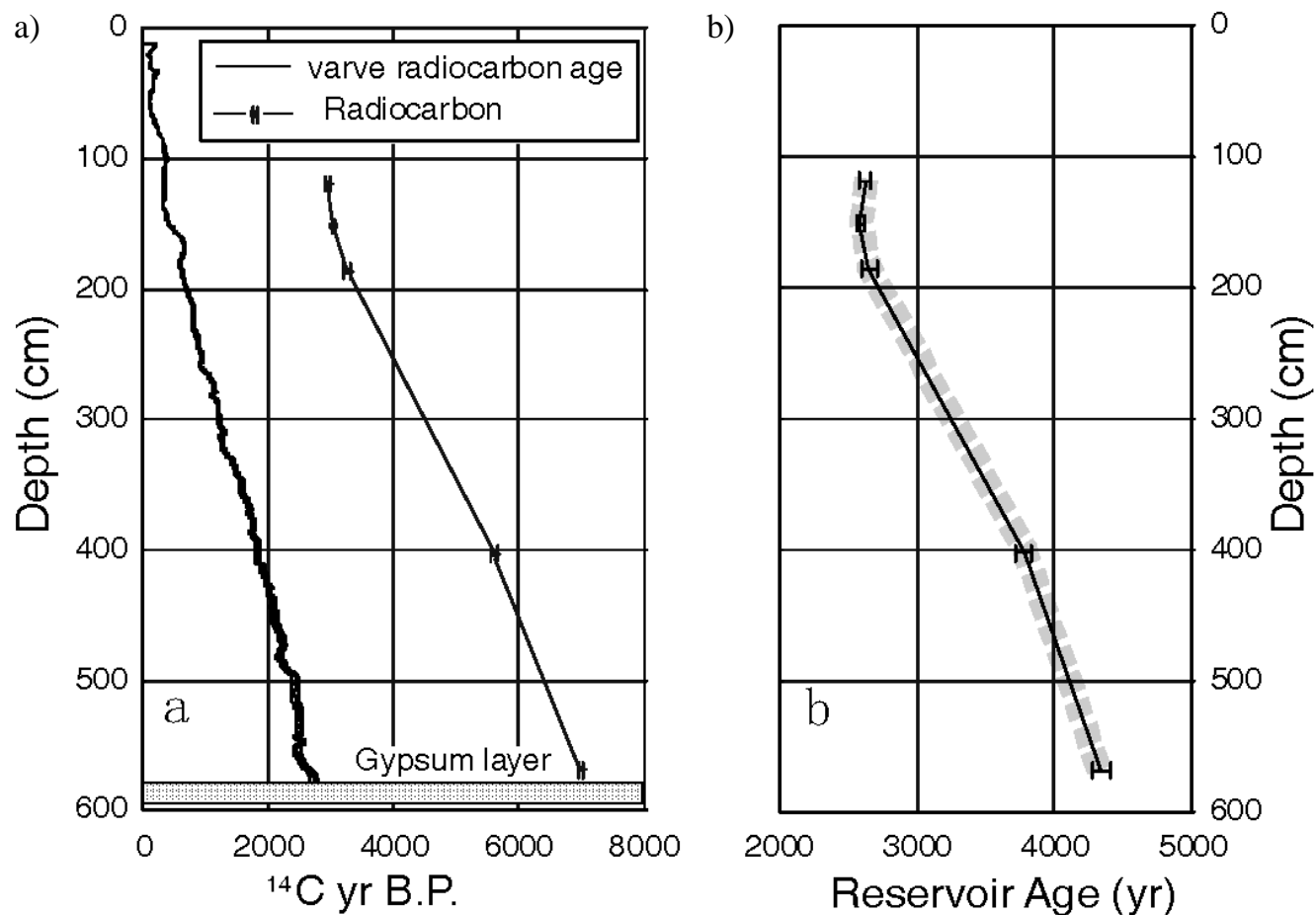

Figure 2 (a) Varve ${ }^{14} \mathrm{C}$ age calculated from IntCal04 and ${ }^{14} \mathrm{C}$ ages on aquatic plant macrofossils on the depth scale and (b) temporal variations of reservoir age.

\section{Radiocarbon Dating}

${ }^{14} \mathrm{C}$ age determinations were performed on aquatic organic samples from core SG00C. The results are shown in Table 1. Four samples are Ruppia matitine seeds and 1 sample is a piece of aquatic plant remains with $\delta^{13} \mathrm{C}_{\mathrm{AMS}}$ values ranging from -9.47 to $-18.29 \%$. The results of AMS ${ }^{14} \mathrm{C}$ dating (Table 1) show that the ${ }^{14} \mathrm{C}$ age at a depth of $119 \mathrm{~cm}$ is $2950 \pm 35 \mathrm{yr} \mathrm{BP}$. Assuming that the sedimentation rate is approximate to $0.4 \mathrm{~mm} / \mathrm{yr}$ and constant above the depth of $119 \mathrm{~cm}$, the surface sediment age obtained by extrapolation along the regression line between depth and ${ }^{14} \mathrm{C}$ age is $\sim 1680 \mathrm{yr}$. Therefore, ${ }^{14} \mathrm{C}$ ages must be significantly affected by the reservoir effect. 
Table $1{ }^{14} \mathrm{C}$ ages and varve ages from Sugan Lake.

\begin{tabular}{|c|c|c|c|c|c|c|c|c|c|}
\hline Lab nr & Sample nr & Material & $\begin{array}{l}\mathrm{Nr} \text { of } \\
\text { seeds }\end{array}$ & $\begin{array}{l}\text { Depth of } \\
\text { SG03E } \\
(\mathrm{cm})\end{array}$ & $\begin{array}{l}\text { Conventional } \\
\text { age (yr BP) }\end{array}$ & $\begin{array}{l}\delta^{13} \mathrm{C}_{\mathrm{AMS}} \\
(\%)\end{array}$ & $\begin{array}{l}\text { Varve age }{ }^{a} \\
\text { (yr BP) }\end{array}$ & $\begin{array}{l}\text { Varve } \\
{ }^{14} \mathrm{C} \text { age }^{\mathrm{b}} \\
(\mathrm{yr} \mathrm{BP})\end{array}$ & $\begin{array}{l}\text { Reservoir } \\
\text { ages }^{c}\end{array}$ \\
\hline KIA18567 & SG-C-090 & Seed & 3 & 119 & $2960 \pm 35$ & -10.15 & $374 \pm 8$ & $333 \pm 11$ & $2627 \pm 37$ \\
\hline KIA18568 & SG-C-117 & Seed & 5 & 152 & $3050 \pm 25$ & -9.47 & $511 \pm 11$ & $459 \pm 17$ & $2591 \pm 30$ \\
\hline KIA18569 & SG-C-144 & Seed & 5 & 186 & $3265 \pm 50$ & -12.80 & $633 \pm 14$ & $612 \pm 18$ & $2653 \pm 53$ \\
\hline KIA18571 & SG-C-378 & Seed & 3 & 403 & $5610 \pm 45$ & -15.43 & $1778 \pm 36$ & $1834 \pm 39$ & $3776 \pm 60$ \\
\hline KIA18572 & SG-C-529 & $\begin{array}{l}\text { Plant } \\
\text { remains }\end{array}$ & - & 569 & $7005 \pm 30$ & -18.29 & $2758 \pm 56$ & $2663 \pm 57$ & $4342 \pm 64$ \\
\hline
\end{tabular}

a Varve uncertainty is under $2 \%$ error.

${ }^{\mathrm{b}}$ The weighted uncertainty is the root of the sum of squares of the errors of the IntCal04 and constituent ${ }^{14} \mathrm{C}$ ages.

${ }^{\mathrm{c}}$ The weighted uncertainty is the root of the sum of squares of the errors of the constituent ${ }^{14} \mathrm{C}$ ages and varve ${ }^{14} \mathrm{C}$ ages.

\section{Reservoir Age in Sugan Lake}

${ }^{14} \mathrm{C}$ reservoir ages in Sugan Lake are evaluated by subtracting the calculated varve ${ }^{14} \mathrm{C}$ age from the measured ${ }^{14} \mathrm{C}$ age in the same stratigraphic horizon (Table 1). ${ }^{14} \mathrm{C}$ reservoir ages in Sugan Lake display temporal changes from 2590 to 4340 yr. During the LIA period, in the depth range $98-160 \mathrm{~cm}$, ${ }^{14} \mathrm{C}$ reservoir ages remained constant $(\sim 2630 \mathrm{yr})$, but they are distinctively different below a depth of $403 \mathrm{~cm}$, with ${ }^{14} \mathrm{C}$ reservoir ages of 3780 and $4340 \mathrm{yr}$ (Figure 2b).

\section{Temporal Variations in Lake Reservoir Ages in Sugan Lake}

At a depth of $569 \mathrm{~cm}$, sample SGC529 yields a ${ }^{14} \mathrm{C}$ age of $7005 \pm 30{ }^{14} \mathrm{C} \mathrm{yr} \mathrm{BP}$, and the comparable calendar age (varve age) and varve-based ${ }^{14} \mathrm{C}$ age are $2758 \pm 56$ and $2663 \pm 57 \mathrm{yr} \mathrm{BP}$, respectively. Thus, there is a quite high reservoir age of $4340 \mathrm{yr}$. In the SG03I core, at depth 574-592 cm, lamination is replaced by a gypsum layer with coarse grain-size crystals. The gypsum layer indicates a hypersalinity stage of lake water. Lake water may have been covered by perennial or very likely perennial salt crust; thus, the strong density stratification due to salinity and extreme stability of the water column developed, which prevented atmospheric exchange. Under these environmental and hydrological conditions, Sugan Lake was supplied by groundwater, which dissolved ${ }^{14} \mathrm{C}$-depleted carbon and induced a high inherited age. A lack of mixing leading to the high residence age comes from in situ aging of lake water in an environment sealed from the atmosphere.

From depths of 403 to $186 \mathrm{~cm}$, the ${ }^{14} \mathrm{C}$ reservoir age significantly decreased compared to the initial section, which suggests that the Sugan Lake came into a different hydrological phase. Above the gypsum layer, the lamination composed of carbonate and organic detritus suggest that lake water became fresh due to the disappearance or diminution of the salt crust by freshwater influx. Under these circumstances, atmospheric ${ }^{14} \mathrm{C}$ would have a chance to exchange with that in lake water; therefore, the increased ${ }^{14} \mathrm{C}$ content led to the decrease of the ${ }^{14} \mathrm{C}$ ages in Sugan Lake.

From depths of 186 to $119 \mathrm{~cm}$, the ${ }^{14} \mathrm{C}$ reservoir effect exhibits a stable phase between $2590-2650$ yr. The data show that Sugan Lake had a relatively stable reservoir age during the LIA time interval (Figure 3). Sugan Lake was in good agreement with this humid period, demonstrated by $\delta^{18} \mathrm{O}$ of carbonate in lake sediment (Zhou 2007a). Two ice-core results (Yao et al. 1996; Liu et al. 1998) near Sugan Lake also suggest that there was a more humid climate in the west of China. During the LIA interval, low $\delta^{18} \mathrm{O}$ of carbonate in lake sediment (Figure 3) shows a different hydrological environment occurred in the Sugan Lake region, namely the supply of lake water changed from groundwater to run-off. The run-off led to a rapid gas equilibration with the atmosphere, as surface water diluted the effect of ancient carbon, making the inherited age relatively low. However, this process 
did not last for long time. During the LIA, high water column, freshwater input, and long ice cover make the reservoir relatively stable at about $2630 \mathrm{yr}$.

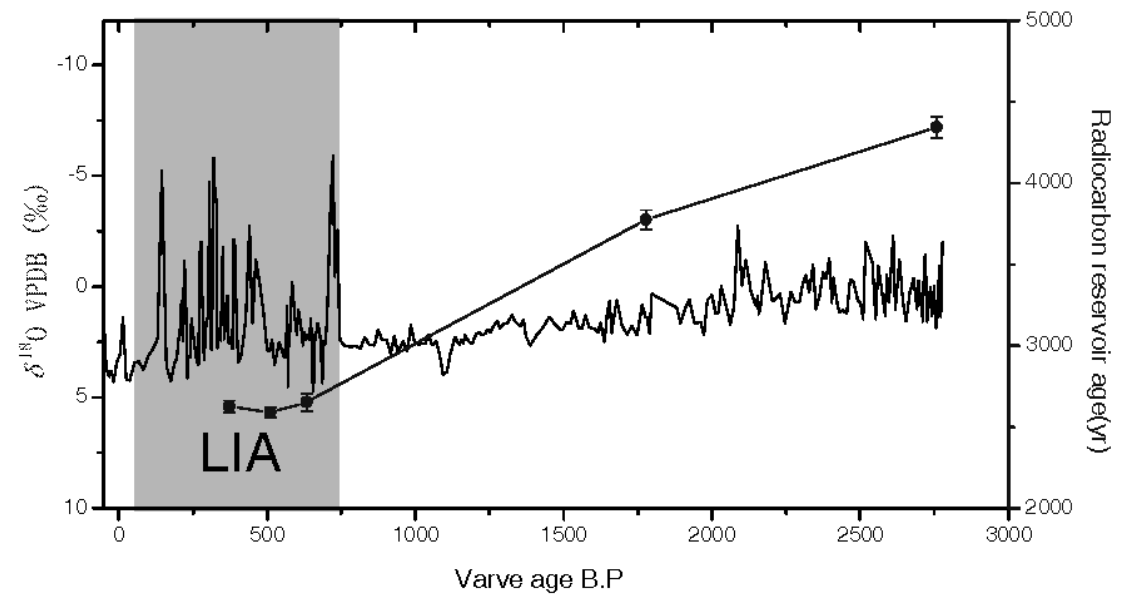

Figure $3 \delta^{18} \mathrm{O}$ of carbonate in lake sediment and ${ }^{14} \mathrm{C}$ reservoir variation

\section{CONCLUSIONS}

The ${ }^{14} \mathrm{C}$ reservoir effect in Sugan Lake generally results from (1) the input of old $\mathrm{CO}_{2}$ either directly from the groundwater, or short streams from groundwater; (2) strong density stratification due to salinity and extreme stability of the water column; and (3) lack of wind-driven mixing, overturn, or atmospheric exchange due to perennial ice cover. In the modern hydrological system of Sugan Lake, the shallow-water column makes density stratification or the stability of the water column impossible.

The changing magnitude of the ${ }^{14} \mathrm{C}$ reservoir effect provides some footprint about the evolution history of Sugan Lake. The lake evolved from a sulfate salt lake into a saline lake. In sulfate salt lake stage, the salt crust prevented the exchange of $\mathrm{CO}_{2}$ with atmosphere, and groundwater with ${ }^{14} \mathrm{C}$ depleted carbon supplied the lake water, which resulted in a high ${ }^{14} \mathrm{C}$ reservoir age. Then, the climate became more and more humid, the lake level increased, the lake water type changed from salt lake to saline, the salt crust was melted by freshwater inflow and the lake water was well aerated. At the onset of the LIA, a humid climate resulted in a fully aerated surface water charging the lake water. Mixing water made the ${ }^{14} \mathrm{C}$ reservoir age low, but the long ice cover made the $\mathrm{CO}_{2}$ exchange with atmosphere not sufficient. According to this study, ${ }^{14} \mathrm{C}$ reservoir ages of the lake in the late Holocene may be driven by hydrological and climatic changes in northwest China. Therefore, attention should be paid to estimation of the ${ }^{14} \mathrm{C}$ reservoir effect when TOC or DIC are used for ${ }^{14} \mathrm{C}$ dating.

\section{ACKNOWLEDGMENTS}

We wish to thank the anonymous reviewers for their insightful comments and invaluable advice; Jianhui Chen, Shun Xiao, Yanbin Lv, Haitao Wei, and Ke Zhang for helping in the field and laboratory work; and technicians Jixiu Cao at Lanzhou University for helping in analyzing the samples. We are grateful for the help from Ms Cashion Callaway who improved the English of the draft. This research was funded by the NSFC Project (40801074, 40721061), Programme of Introducing Talents of Discipline to Universities (B06026), Ministry of Education and PhD Program Foundation of Ministry of Education of China (20060730003). 


\section{REFERENCES}

Belmaker R, Stein M, Yechieli Y, Lazar B. 2007. Controls on the radiocarbon reservoir ages in the modern Dead Sea drainage system and in the last Glacial Lake Lisan. Radiocarbon 49(2):969-82.

Chen FH, Zhu Y, Li JJ, Shi Q, Jin LY, Wünnemann B. 2001. Abrupt Holocene changes of the Asian monsoon at millennial- and centennial-scales: evidence from lake sediment document in Minqin Basin, north China. Chinese Science Bulletin 46(23):1942-7.

Colman SM, Jones GA, Rubin M, King JW, Peck JA, Orem WH. 1996. AMS radiocarbon analyses from Lake Baikal, Siberia: challenges of dating sediments from a large, oligotrophic lake. Quaternary Science Reviews 15(7):669-84.

Culleton BJ. 2006. Implications of a freshwater radiocarbon reservoir correction for the timing of late Holocene settlement of the Elk Hills, Kern County, California. Journal of Archaeological Science 33(9): 1331-9.

Geyh M, Schotterer U, Grosjean M. 1998. Temporal changes of the ${ }^{14} \mathrm{C}$ reservoir effect in lakes. Radiocarbon 40(2):921-31.

Goslar T, Pazdur A, Pazdur MF, Walanus A. 1989. Radiocarbon and varve chronologies of annually laminated lake sediments of Gościąż Lake. Radiocarbon 31(3):940-7.

Grootes PM, Nadeau MJ, Rieck A. 2004. ${ }^{14}$ C-AMS at the Leibniz-Labor: radiometric dating and isotope research. Nuclear Instruments and Methods in Physics Research B 223-224:55-61.

Hajdas I, Bonani G, Goslar T. 1995. Radiocarbon dating the Holocene in the Gościąż lake floating varve chronology. Radiocarbon 37(1):71-4.

Hall BL, Henderson GM. 2001. Use of uranium-thorium dating to determine past ${ }^{14} \mathrm{C}$ reservoir effects in lakes: examples from Antarctica. Earth and Planetary Science Letters 193(3):565-77.

Hendy CH, Hall BL. 2006. The radiocarbon reservoir effect in proglacial lakes: examples from Antarctica. Earth and Planetary Science Letters 241(3-4):41321

Hutchinson I, James TS, Reimer PJ, Bornhold BD, Clague JJ. 2004. Marine and limnic radiocarbon reservoir corrections for studies of late- and postglacial environments in Georgia Basin and Puget Lowland, British Columbia, Canada and Washington, USA. Quaternary Research 61(2):193-203.

Liu KB, Yao ZY, Thompson LG. 1998. A pollen record of Holocene climatic changes from Dunde ice cap, Qinghai-Tibetan Plateau. Geology 26(2):135-8.

Moreton SG, Rosqvist GC, Davies SJ, Bentley MJ. 2004. Radiocarbon reservoir ages from freshwater lakes, South Georgia, sub-Antarctic: modern analogues from particulate organic matter and surface sediments. $R a$ diocarbon 46(2):621-6.

Ojala AEK, Saarnisto M. 1999. Comparative varve counting and magnetic properties of the 8400 -yr se- quence of an annually laminated sediment in Lake Valkiajärvi, central Finland. Journal of Paleolimnology 22(4):335-48.

Ojala AEK, Heinsalu A, Saarnisto M, Tiljander M. 2005. Annually laminated sediments date the drainage of the Ancylus Lake and early Holocene shoreline displacement in central Finland. Quaternary International 130(1):63-73.

Qiang MR, Chen FH, Zhang JW, Gao SY, Zhou AF. 2005. Climatic changes documented by stable isotopes of sedimentary carbonate in Sugan Lake, northeastern Tibetan Plateau of China, since 2 ka BP. Chinese Science Bulletin 50(17):1930-9.

Reimer PJ, Baillie MGL, Bard E, Bayliss A, Beck JW, Bertrand CJH, Blackwell PG, Buck CE, Burr GS, Cutler KB, Damon PE, Edwards RL, Fairbanks RG, Friedrich M, Guilderson TP, Hogg AG, Hughen KA, Kromer B, McCormac G, Manning S, Bronk Ramsey C, Reimer RW, Remmele S, Southon JR, Stuiver M, Talamo S, Taylor FW, van der Plicht J, Weyhenmeyer CE. 2004. IntCal04 terrestrial radiocarbon age calibration, 0-26 cal kyr BP. Radiocarbon 46(3):1029-58.

Renberg I. 1981. Improved methods for sampling, photographing and varve counting of varved lake sediments. Boreas 10(3):255-8.

Shen J, Liu XQ, Wang SM, Ryo M. 2005. Palaeoclimatic changes in the Qinghai Lake area during the last 18,000 years. Quaternary International 136(1):131-40.

Simola H. 1977. Diatom succession in the formation of annually laminated sediment in Lovojärvi, a small eutrophicated lake. Annales Botanicae Fennici 14: 143-8.

Stein M, Migowski C, Bookman R, Lazar B. 2004. Temporal changes in radiocarbon reservoir age in the Dead Sea Lake Lisan system. Radiocarbon 46(2):649-55.

Stiller M, Kaufman A, Carmi I, Mintz G. 2001. Calibration of lacustrine sediment ages using the relationship between ${ }^{14} \mathrm{C}$ levels in lake waters and in the atmosphere: the case of Lake Kinneret. Radiocarbon 43(2B):821-30.

Yao TD, Thompson LG, Qin DH, Tian LD, Jiao KQ, Yang ZH, Xie C. 1996. Variations in temperature and precipitation in the past 2000a on the Xizang (Tibet) Plateau-Guliya ice core record. Science in China (Series D) 26(4):426-33.

Yu SY, Shen J, Colman SM. 2007. Modeling the radiocarbon the radiocarbon reservoir effect in lacustrine systems. Radiocarbon 49(3): 1241-54.

Zhou AF. 2007a. Varve chronology and Late Holocene environmental changes in Sugan Lake, northern Qaidam Basin [PhD dissertation]. Lanzhou University.

Zhou AF, Chen FH, Qiang M-R, Yang ML, Zhang JW. 2007b. The discovery of annually laminated sediments (varves) from shallow Sugan Lake in inland arid China and their paleoclimatic significance. Science in China (Series D) 50(8):1218-24. 